\title{
B-Cell Activating Factor (BAFF) in Systemic Lupus Erythematosus, Rheumatoid Arthritis, and Behçet's Disease
}

\author{
Sistemik Lupus Eritematozus, Romatoid Artrit ve Behçet Hastalığında \\ B Hücre Aktive Edici Faktör (BAFF)
}

\author{
Amina Badr ELDIN, ${ }^{1}$ Safaa SAYED, ${ }^{2}$ Gehan HEGAZY, ${ }^{3}$ Olfat SHAKER $^{4}$ \\ ${ }^{1}$ Department of Internal Medicine, Ain Shams University, Faculty of Medicine, Cairo, Egypt; \\ ${ }^{2}$ Department of Rheumatology \& Rehabilitation, Cairo University, Faculty of Medicine, Cairo, Egypt; \\ ${ }^{3}$ Department of Clinical Biochemistry, King Abdulaziz University, Faculty of Medicine, Jeddah, Saudi Arabia; \\ ${ }^{4}$ Department of Medical Biochemistry, Cairo University, Faculty of Medicine, Cairo, Egypt
}

\begin{abstract}
Objectives: This study aims to determine B-cell activating factor (BAFF) serum levels in rheumatoid arthritis (RA), systemic lupus erythematosus (SLE) and Behçet's disease (BD) and correlate these levels with disease activity and severity.

Patients and methods: Between December 2010 and December 2011, 63 Egyptian patients with collagen diseases [RA $(n=21)$, SLE $(n=21) ; B D(n=21)]$ were recruited from Cairo and Ain Shams University Hospitals, along with 21 apparently healthy individuals as controls. All participants underwent history taking, clinical examination, laboratory and radiological investigations, and disease activity score estimation. The serum BAFF level was measured by an enzyme-linked immunosorbent assay (ELISA) kit.
\end{abstract}

Results: The BAFF serum levels were significantly elevated in patients with SLE and BD versus the healthy controls $(p<0.011$, $\mathrm{p}<0.023)$ and in SLE versus RA and $B D(p<0.024, p<0.026)$. A significant positive correlation was found between the BAFF and C-reactive protein (CRP) $(r=0.928, p<0.0001)$, the Disease Activity Score 28 (DAS28) $(r=0.810, p<0.0001)$, and disease control $(r=0.834, p<0.0001)$ in RA. Also, a significant positive correlation was found between BAFF and SLE Disease Activity Index (SLEDAI) score classification $(r=0.894, p<0.0001)$ and SLEDAI score $(r=0.748, p<0.0001)$ in SLE as well as between the BAFF and disease duration $(r=0.578, p<0.006)$ in BD.

Conclusion: The BAFF serum levels are increased in patients with SLE and BD versus the controls and in patients with SLE compared with those with RA and BD. They also have a positive correlation with disease severity in SLE and RA, which suggests that BAFF may play a role in the pathogenesis and activity of these diseases. These results may pose the possibility that a human monoclonal antibody drug which selectively inhibits BAFF biological activity may be useful in the treatment of active resistant cases.

Key words: Behçet's disease; disease activity; rheumatoid arthritis; serum B-cell activating factor; systemic lupus erythematosus.
Amaç: $\mathrm{Bu}$ çalışmada romatoid artrit $(\mathrm{RA})$, sistemik lupus eritematozus (SLE) ve Behçet hastalığında $(\mathrm{BH}) \mathrm{B}$ hücre aktive edici faktör (BAFF) serum düzeyleri ve bu düzeylerin hastalık aktivitesi ve şiddeti ile olan ilişkisi araştırıldı.

Hastalar ve yöntemler: Aralık 2010 - Aralık 2011 tarihleri arasında, Kahire ve Ain Shaims Üniversite Hastanelerinden kolajen hastalığı olan 63 Mısırlı hasta [RA $(n=21)$, SLE $(n=21)$, $\mathrm{BH}(\mathrm{n}=21)]$ ve beraberinde görünüşü sağlıklı olan 21 kişi kontrol grubu olarak çalışmaya dahil edildi. Katılımcıların tümünün öyküsü alındı, klinik muayenesi ve laboratuvar ve radyolojik incelemeleri yapıldı ve hastalık aktivite skoru hesaplandı. Serum BAFF düzeyi, enzim bağlı immünosorbent assay (ELISA) kiti ile ölçüldü.

Bulgular: BAFF serum düzeyleri, sağlıklı kontrollere kıyasla SLE ve $B H$ hastalarında $(p<0.011, p<0.023)$ ve $R A$ ve $B H$ 'ye kıyasla SLE hastalarında $(p<0.024, p<0.026)$ anlamlı düzeyde daha yüksekti. Romatoid artritte BAFF ve C-reaktif protein (CRP) $(r=0.928, p<0.0001)$, Hastalık Aktivite Skoru 28 (DAS28) $(r=0.810, p<0.0001)$ ve hastalık kontrolü arasında $(r=0.834$, $\mathrm{p}<0.0001)$ anlamlı bir pozitif ilişki saptandı. Ayrıca SLE'de BAFF ve SLE Hastalık Aktivite İndeksi (SLEDAI) skor sınıflandırması $(r=0.894, p<0.0001)$ ve SLEDAl skoru arasında $(r=0.748$, $p<0.0001)$ ve $B H$ 'de BAFF ve hastalık süresi arasında da $(r=0.578, p<0.006)$ anlamlı bir pozitif ilişki saptandı.

Sonuç: Kontrol grubuna kıyasla, SLE ve $\mathrm{BH}$ hastalarında ve RA ve BH hastalarına kıyasla SLE hastalarında BAFF serum düzeyleri yüksektir. Ayrıca SLE ve RA'da, BAFF'nin bu hastalıkların patogenezi ve aktivitesinde rol oynayabileceğini gösterebilen, hastalık şiddeti açısından pozitif bir ilişki de mevcuttur. Bu bulgular, selektif olarak BAFF biyolojik aktivitesini inhibe eden insan monoklonal antikor ilacının, aktif dirençli olguların tedavisinde faydalı olabilme olasılığını akla getirmektedir.

Anahtar sözcükler: Behçet hastalı̆ı; hastalık aktivitesi; romatoid artrit; serum $B$ hücre aktive edici faktör; sistemik lupus eritematozus.

Received: January 30, 2012 Accepted: June 27, 2012

Correspondence: Gehan Hegazy, M.D. Department of Clinical Biochemistry, King Abdulaziz University, Faculty of Medicine, Jeddah, Saudi Arabia.

Tel: 00966542843217 e-mail: gehanhegazy@hotmail.com

(02012 Turkish League Against Rheumatism. All rights reserved. 
B cells are not only involved in the production of antibodies, but also serve as antigen-presenting cells which co-regulate $\mathrm{T}$ cell activation through cytokine production. ${ }^{[1]}$ The $\mathrm{B}$-cell activating factor (BAFF) is a key $\operatorname{cog}$ in the survival of $B$ cells and ensures their existence through reducing apoptotic clearance. ${ }^{[2]}$ It belongs to the tumor necrosis factor (TNF) ligand super family ${ }^{[3]}$ and consists of a transmembrane protein, from which a biologically active soluble $27 \mathrm{kD}$ protein is cleaved. ${ }^{[4]}$ The BAFF is produced by myeloid lineage cells, malignant $\mathrm{B}$ cells, activated $\mathrm{T}$ cells, and bone marrow stromal cells ${ }^{[5]}$ and has three receptors that belong to the TNF receptor superfamily: the $\mathrm{B}$ cell maturation antigen (BCMA), the transmembrane activator, calcium-modulator and cyclophilin ligand interactor (TACI), and the BAFF receptor (BAFF-R). ${ }^{[6]}$ These receptors are primarily expressed in $B$ cells, but TACI and BAFF-R are known to be expressed by T cell subsets as well. ${ }^{[7]}$ Because of the receptor distribution, the studies on the BAFF have focused on $B$ cells and $T$ cells. It has been shown that the BAFF is responsible for $B$ cell survival and maturation, ${ }^{[8]}$ and it is essential for the development of B cell tolerance. A breakdown of the regulation of the BAFF expression results in excessive production that impairs B cell tolerance and leads to autoimmune phenomena. ${ }^{[9]}$ The BAFF also functions as a $\mathrm{T}$ cell co-stimulatory molecule. ${ }^{[10]}$

Systemic lupus erythematosus (SLE) is a complicated autoimmune disease. Although selfreactive $B$ cells produce the autoantibodies essential for the diagnosis of the disease, B cells have proven in recent years to be active participants in the development of this disease irrespective of autoantibody production. In light of this advancement, a central question surrounding the pathogenesis of the disease is whether intrinsic defects in SLE B cells play a role in triggering the immunological events that result in the onset of clinical disease. Although other immune cells play a role in SLE, B cells from SLE patients display signaling defects that may underlie the pathogenesis and explain the characteristic hyperactivity of $\mathrm{B}$ cells in active disease. ${ }^{[1]}$ The classic paradigm for rheumatoid arthritis (RA) pathogenesis holds that CD4+ $\mathrm{T}$ cells mediate joint damage both directly and by driving non-T effector cells to release inflammatory cytokines. In contrast, the new paradigm that is developing centers on an interaction of $\mathrm{CD} 4+\mathrm{T}$ cells with $\mathrm{B}$ cells and the fact that autoreactive $\mathrm{B}$ cells can be driven by the $\mathrm{T}$ cells to produce immunoglobuline $\mathrm{G}$ (IgG) autoantibodies that may be directly involved in joint damage. It is well known that $B$ cells are critical in the activation of CD4+ T cells. ${ }^{[12]}$

Behçet's disease (BD) is a complex multisystem vasculitis of unknown etiology. In this disease, four major symptoms are evident: recurrent oral aphthous ulcers, skin lesions, ocular lesions, and genital ulcers. In addition, minor symptoms such as articular manifestations, involvement of the digestive tract, epididymitis, vascular involvement, and neuropsychiatric symptoms can also be found. In $\mathrm{BD}$, venous involvement is common, whereas arterial involvement is rare. ${ }^{[13]}$ It is recognized that atherothrombosis in systemic inflammatory disorders is closely related to abnormalities associated with coagulation and lipid metabolism. ${ }^{[14]}$ The precise mechanisms of tissue destruction in BD have not been fully elucidated. Nevertheless, a growing number of reports have involved the investigation of $\mathrm{T}$ and $\mathrm{B}$ lymphocyte-mediated immune responses. ${ }^{[15]}$ Recently, resistant cases of retinal vasculitis due to $\mathrm{BD}$ have been treated successfully with rituximab, a chimeric, monoclonal antibody that acts against the specific B cell antigen, CD20. The recent success of rituximab in cases of autoimmune diseases which are considered to be $\mathrm{T}$ cell-mediated, like $\mathrm{BD}$, indicates that $\mathrm{B}$ cells must have a much broader role in the pathogenesis of this disease than has been previously thought. ${ }^{[16]}$

The aim of this study was to determine and compare the serum level of the BAFF in patients with RA, SLE, and $\mathrm{BD}$ and also to correlate its serum level with disease activity indices and severity.

\section{PATIENTS AND METHODS}

This retrospective study included 63 Egyptian patients with collagen diseases from outpatient clinics of the Internal Medicine and Rheumatology Departments of Cairo and Ain Shams University Hospitals between December 2010 and December 2011 as well as 21 apparently healthy individuals who were either on the medical staff or were patient's relatives that served as the healthy controls. The study was conducted according to the principles of the Helsinki Declaration and was approved by the local ethics committee of the Faculty of Medicine of Cairo University. Informed written consent was obtained from all subjects who participated in this study after explaining the aim and nature of the study.

The patients were subdivided into three groups according to clinical diagnosis. The SLE group 
included 21 patients who fulfilled at least four of the American College of Rheumatology (ACR) criteria for SLE diagnosis. ${ }^{[17]}$ Assessment of disease activity was achieved using the SLE Disease Activity Index (SLEDAI) score. ${ }^{[18]}$ Patients with evidence of pre-existing renal diseases, malignancy, concurrent infection, or a history of nephrotoxic drug use were excluded from this study.

The RA group included 21 patients who fulfilled the ACR criteria for classification of RA. ${ }^{[19]}$ The disease activity of RA was assessed with the Disease Activity Score 28 (DAS28). ${ }^{[20]}$ Patients were categorized as having severe disease activity (score $>5.1$ ), moderate disease activity (score 3.2-5.1), and low disease activity (score 2.6-3.2). A score of $<2.6$ signified remission. ${ }^{[21]}$ The Health Assessment Questionnaire for Disability Index (HAQ DI) was used to assess the participants, and a score of $<0.3$ was considered to be normal. ${ }^{[22]}$

The BD group included 21 patients who fulfilled the International Study Group criteria for BD. ${ }^{[23]}$ This group established the diagnostic criteria for this disease and made recurrent oral ulcers a mandatory finding. Patients also needed to have two out of four of the following: recurrent genital ulcers, eye involvement, or skin lesions or positive pathergy test. ${ }^{[23]}$ Various tissue types, for instance blood vessel, eye, skin, mucosa, joint, or central nervous system (CNS), may be affected during the course of BD. ${ }^{[24]}$ The healthy control group included 21 volunteers whose ages matched those of the disease groups. A complete medical history was obtained from each participant, and they also underwent physical and joint examinations as well as laboratory and radiological investigations.

Five milliliters of blood was obtained from all participants via venipuncture and placed into plain tubes for further investigation. A complete blood count (Coulter STKS hematology flow cytometer, Block Scientific, Inc., Bohemia, New York, USA) was conducted and all patients were evaluated with regard to; the erythrocyte sedimentation rate (ESR), $\mathrm{C}$-reactive protein (CRP), and serum creatinine and lipids profile [total cholesterol (TC), triglyceride (TG), low density lipoprotein cholesterol (LDLC), and high density lipoprotein cholesterol (HDLC)]. The ESR was measured by using the Westergren method and expressed in $\mathrm{mm} / \mathrm{h} \cdot{ }^{[25]}$ The CRP levels were measured by the turbidimetric method using a photometer (Biosystems S.A., Barcelona, Spain), and a level of $<6 \mathrm{mg} / \mathrm{L}$ was accepted as normal. The TC, TG, HDLC, and LDLC were determined by a Randox reagent kit (Randox Laboratories Ltd., Crumlin, UK).

The serum BAFF concentration was determined with a quantitative sandwich enzyme immunoassay technique (Quantikine ${ }^{ø}$ Human BAFF Immunoassay, R\&D Systems, Minneapolis, Minnesota, USA). Shortly thereafter, polystyrene microplate wells were coated with a mouse monoclonal antibody against the BAFF, and after incubation with the serum, the assay was developed with a polyclonal second antibody against the BAFF conjugated to horseradish peroxidase. After a wash to remove the unbound antibody-enzyme reagent, a substrate solution was added to develop color in proportion to the amount of the bound BAFF. After stopping the development, color intensity was then measured by an automated microplate reader at $450 \mathrm{~nm}$ (E-Max, Molecular Devices Corporation, Sunnyvale, California USA). The recommendations made by the manufacturer were followed throughout. Standard curves were derived from serial dilutions of $40 \mathrm{ng}$ of recombinant human BAFF, and both negative $(\mathrm{H} 2 \mathrm{O})$ and positive control sera were included in each run. All measurements were done twice, and the results were averaged, with the intra-assay variation being between $2 \%$ and $12 \%$. The lower detection limit of this assay was $3.38 \mathrm{pg} / \mathrm{ml}$.

For SLE patients, the following investigations were conducted: a quantitative measurement of 24-hour urinary proteins and a complete urine analysis, indirect immunofluorescence (IF) antibody tests (IMMCO Diagnostics, Inc., Buffalo, New York, USA) for the detection and quantification of antinuclear antibodies (ANA), a quantitative estimation using a tubitimer (Siemens, Marburg, Germany) for the detection of serum C3 and C4 levels, a test for lupus anticoagulant antibodies (LAC) with an LAC screening reagent kit (Siemens, Deerfield, Illinois, USA) that was actually a simplified diluted Russell's viper venom test (d.RVVT); a test for anticardiolipin antibodies (ACL) using an enzyme-linked immunoaorbent assay (ELISA) kit (R\&D Systems, Minneapolis, MN) for the detection of IgG-IgA, and a test for IgM classes of anticardiolipin antibodies using (IMMCO Diagnostics) catalog No. 11185. An anti-ds-DNA titer was detected with an ELISA kit (R\&D Systems, Minneapolis, MN). Renal biopsies guided by abdominal ultrasound (US) were done after written consent from the SLE patients was obtained to search for clinical and laboratory evidence of renal involvement. The renal biopsy cores were then fixed in $10 \%$ neutral formalin and paraffinized. Next, serial sections 4 microns thick were taken for 
histopathological examination. The sections were stained with Hematoxylin and Eosin (H\&E) before examination under a light microscope. The cases were categorized according to the modified World Health Organization (WHO) classification formulated for glomerular dieases. ${ }^{[26]}$ The histopathological features were scored according to the renal activity and chronicity indices. ${ }^{[27]}$ An immunoflurescent microscopic examination was designed for biopsies with negative light microscopic findings.

For the RA group, the rheumatoid factor (RF) was done with latex. For the BD patient group, a lipid profile, resting electrocardiogram, and echocardiograph were performed. Further in-depth investigations for selected patients that had positive or suggestive findings for cardiac or major vessel affection on clinical examination were also conducted along with standard investigations such as chest X-ray, chest computed tomography (CT), and arterial and venous Doppler US.

\section{Statistical methods}

Quantitative data was presented as means and standard deviation (SD) values while qualitative data was presented as frequencies and percentages. Kruskal-Wallis and one-way ANOVA were used for comparison of more than two quantitative data as appropriate. The MannWhitney U test was used for pair-wise comparisons, and a chi-square test was used for studying the comparisons between different qualitative variables. The significance level was set at $\mathrm{p} \leq 0.05$. Person correlation was used for parametric variables while Sperman correlation was used for non parametric variables. Statistical analysis was performed with SPSS version 16.0 for Windows (SPSS Inc., Chicago, Illinois, USA).

\section{RESULTS}

The demographic characteristics of the patients and controls are revealed in Table 1. The duration of SLE was significantly elevated compared with RA and $\mathrm{BD}$ $(\mathrm{p}<0.0001$ for both).
The clinical characteristics of the RA patients are seen in Table 2. More patients (42.9\%) showed moderate disease activity (score $3.2-5.1$ ) while $33.3 \%$ showed remission $(<2.6), 14.3 \%$ showed severe disease activity ( $>5.1$ ), and $9.5 \%$ showed low disease activity (score 2.6-3.2). The most common comorbidities were osteoporosis and tuberculosis (14.3\% for both).

The clinical characteristics of the SLE patients are shown in Table 3. The most common comorbidity was proteinuria (76.2\%). According to the SLEDAI classification, $52.4 \%$ of the patients showed moderate disease while $28.6 \%$ showed severe disease, $14.3 \%$ showed mild disease, and only $4.8 \%$ showed very severe disease. The renal biopsy classification was $42.8 \%$ stage IV while $28.6 \%$ were stage III, $21.4 \%$ were stage II, and only $7.1 \%$ were stage V. Active nephritis was found in $42.8 \%$ of the cases.

The clinical characteristics of the $\mathrm{BD}$ patients are provided in Table 4 . All the patients (100\%) had oral ulcers while $85.7 \%$ of patients had genital ulcers, $52.4 \%$ had uveitis, $38.1 \%$ had deep vein thrombosis (DVT), $28.6 \%$ had arthritis, $19.0 \%$ had erythema nodosum, $14.3 \%$ had erythema nodosum vasculitis, and $4.8 \%$ had hypertension, hepatitis, or tuberculosis.

The BAFF serum levels were significantly elevated in patients with SLE and BD versus the healthy controls $(p<0.011$ and $p<0.023$, respectively) and were also higher in the SLE group versus the groups with RA and BD $(\mathrm{p}<0.024$ and $\mathrm{p}<0.026$, respectively). The TC levels were significantly elevated for patients with RA, SLE, and BD versus the healthy controls $(p<0.0001$ for all) and for those with SLE versus RA and BD $(\mathrm{p}<0.002$ and $\mathrm{p}<0.011$, respectively). The TG levels were significantly increased in the RA, SLE and BD groups versus the control group $(\mathrm{p}<0.014, \mathrm{p}<0.0001$, and $\mathrm{p}<0.0001$, respectively) and for patients with SLE versus those with RA and $\mathrm{BD}$ ( $\mathrm{p}<0.0001$ for both). The levels of TG were also higher for participants with $\mathrm{BD}$ versus those with RA $(\mathrm{p}<0.007)$. The HDLC level was

Table 1. Demographic characteristics of the different groups

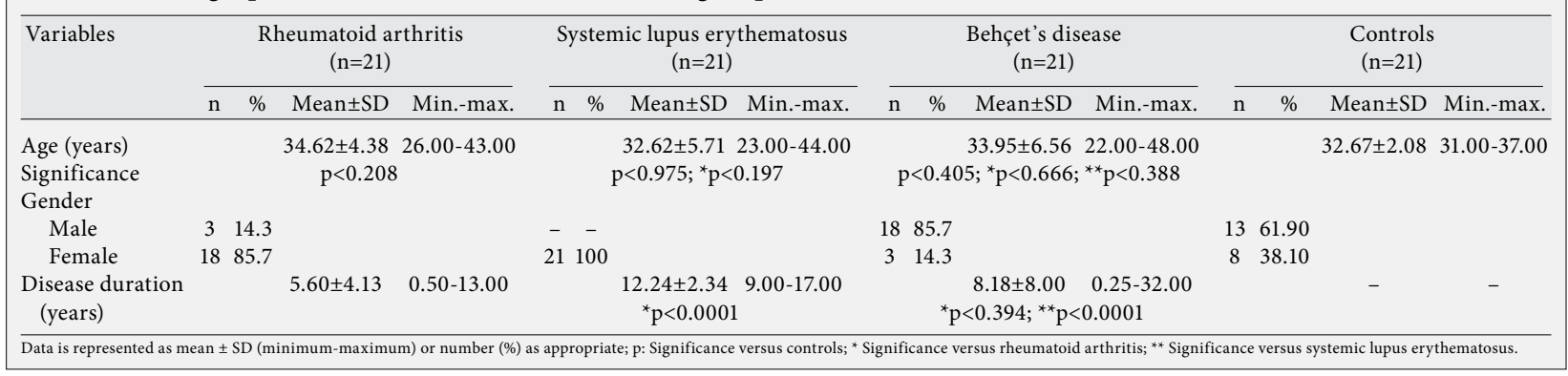




\begin{tabular}{|c|c|c|c|c|}
\hline Variables & $\mathrm{n}$ & $\%$ & Mean \pm SD & Min.-max. \\
\hline Morning stiffness & & & $26.10 \pm 36.73$ & $0.00-120.0$ \\
\hline Number of swollen joints & & & $2.81 \pm 5.50$ & $0.00-18.0$ \\
\hline Number of tender joints & & & $4.33 \pm 5.83$ & $0.00-20.0$ \\
\hline DAS28 score & & & $3.68 \pm 1.59$ & $1.38-7.66$ \\
\hline \multicolumn{5}{|l|}{ Disease control } \\
\hline Remission $(<2.6)$ & 7 & 33.3 & & \\
\hline Low disease activity (score 2.6-3.2) & 2 & 9.5 & & \\
\hline Moderate disease activity (score 3.2-5.1) & 9 & 42.9 & & \\
\hline Severe disease activity $(>5.1)$ & 3 & 14.3 & & \\
\hline HAQ total & & & $0.87 \pm 0.62$ & $0.00-2.30$ \\
\hline \multicolumn{5}{|l|}{ Comorbidity } \\
\hline Osteoporosis & 3 & 14.3 & & \\
\hline Tuberculosis & 3 & 14.3 & & \\
\hline Subcutaneous nodules & 2 & 9.5 & & \\
\hline Hepatitis $\mathrm{C}$ virus & 2 & 9.5 & & \\
\hline Hypertension & 2 & 9.5 & & \\
\hline Hepatitis B virus & 1 & 4.8 & & \\
\hline Maculopathy & 1 & 4.8 & & \\
\hline Diabetes mellitus & 1 & 4.8 & & \\
\hline
\end{tabular}

significantly lower in the SLE group versus the control and RA groups $(\mathrm{p}<0.002$ and $\mathrm{p}<0.001$, respectively). The LDLC level was significantly elevated in the patients with SLE versus the control, RA and BD groups $(\mathrm{p}<0.0001$ for all). The CRP levels were significantly higher in the RA and SLE groups when compared with the healthy control group $(\mathrm{p}<0.0001$ for both), and they were higher for patients with RA versus those with SLE and $B D(p<0.0001$ for both). Furthermore, the CRP levels were elevated for patients with SLE versus those with $B D(p<0.0001)$. The ESR was significantly increased in the RA, SLE and BD groups versus the healthy controls $(\mathrm{p}<0.0001, \mathrm{p}<0.006$, and $\mathrm{p}<0.0001$, respectively) (Table 5).

A significant positive correlation existed between the BAFF and the CRP $(r=0.928, p<0.0001)$, DAS28 score $(\mathrm{r}=0.810, \mathrm{p}<0.0001)$, and disease control $(\mathrm{r}=0.834$, $\mathrm{p}<0.0001)$ in the RA group. Additionally, there was a significantly positive correlation between the BAFF and the SLEDAI score classification $(\mathrm{r}=0.894, \mathrm{p}<0.0001)$ and SLEDAI score $(\mathrm{r}=0.748, \mathrm{p}<0.0001)$ in the SLE group and between the BAFF and disease duration $(\mathrm{r}=0.578, \mathrm{p}<0.006)$ in the BD group (Table 6).

\section{DISCUSSION}

The BAFF is an important regulator of B cell activation, proliferation, and immunoglobulin production. ${ }^{[28]}$
Exaggerated activation of the B cells and $\mathrm{T}$ cells by the BAFF results in the development and/or worsening of autoimmune diseases. ${ }^{[29]}$ In this study, the serum levels of the BAFF in SLE patients were significantly higher than for the control, RA, and BD groups. In partial agreement with our results, Zhang et al. ${ }^{[30]}$ reported a significant increase in the level of the BAFF in SLE patients when compared with healthy controls. BeckerMerok et al. ${ }^{[31]}$ reported that the levels of serum BAFF were higher in patients with SLE $(n=42)$ and RA $(n=60)$ when compared with the control group, and they were also higher in patients with SLE than in those with RA (median 2.7 versus $1.4 \mathrm{ng} / \mathrm{ml}, \mathrm{p}<0.010$ ). Zhao et al. ${ }^{[32]}$ reported elevated BAFF levels and a proliferationinducing ligand (APRIL) plasma levels in SLE patients when compared with the healthy control group in their study. Moreover, in their study, the BAFF serum levels were positively correlated with disease severity (SLEDAI score). Other studies of a larger cohort of SLE patients suggested that there is a significant correlation between the serum BAFF levels and SLEDAI scores across all patient visits combined over time. ${ }^{[33]}$ Becker-Merok et al. ${ }^{[31]}$ reported that SLE patients with increased BAFF levels had higher SLEDAI scores, but they also found that the BAFF levels correlated inversely with age. Zhao et al. ${ }^{[32]}$ found a significant positive correlation between the BAFF levels and SLEDAI scores. In a separate report, ${ }^{[30]}$ the same authors reported that 


\begin{tabular}{|c|c|c|c|c|}
\hline Variables & $\mathrm{n}$ & $\%$ & Mean \pm SD & Min.-max. \\
\hline \multicolumn{5}{|l|}{ Comorbidity } \\
\hline Proteinuria & 16 & 76.2 & & \\
\hline Pyuria & 15 & 71.4 & & \\
\hline Hypertension & 13 & 61.9 & & \\
\hline Hematuria & 11 & 52.4 & & \\
\hline Arthritis & 6 & 28.6 & & \\
\hline Fever & 5 & 23.8 & & \\
\hline Mucosal ulcers & 4 & 19.0 & & \\
\hline Psychosis & 4 & 19.0 & & \\
\hline Pleurisy & 3 & 14.3 & & \\
\hline Urinary casts & 3 & 14.3 & & \\
\hline Vasculitis & 3 & 14.3 & & \\
\hline New rash & 3 & 14.3 & & \\
\hline Alopecia & 3 & 14.3 & & \\
\hline Seizures & 2 & 9.5 & & \\
\hline Cerebrovascular accident & 2 & 9.5 & & \\
\hline Venous thrombosis & 2 & 9.5 & & \\
\hline Headache & 1 & 4.8 & & \\
\hline Pericarditis & 1 & 4.8 & & \\
\hline Myositis & 1 & 4.8 & & \\
\hline Organic brain syndrome & 1 & 4.8 & & \\
\hline Arterial thrombosis & 1 & 4.8 & & \\
\hline Peripheral neuropathy & 1 & 4.8 & & \\
\hline Antinuclear antibodies & 21 & 100.0 & & \\
\hline Low complement & 16 & 76.2 & & \\
\hline Increased DNA binding & 15 & 71.4 & & \\
\hline Lupus anticoagulant antibodies & 5 & 23.8 & & \\
\hline Anticardiolipin antibodies & 5 & 23.8 & & \\
\hline Leucopenia & 3 & 14.3 & & \\
\hline SLEDAI score & & & $19.95 \pm 9.28$ & $8.00-46.00$ \\
\hline \multicolumn{5}{|l|}{ SLEDAI classification } \\
\hline Mild & 3 & 14.3 & & \\
\hline Moderate & 11 & 52.4 & & \\
\hline Severe & 6 & 28.6 & & \\
\hline Very severe & 1 & 4.8 & & \\
\hline \multicolumn{5}{|l|}{ Renal biopsy class } \\
\hline II & 3 & 14.3 & & \\
\hline III & 11 & 52.4 & & \\
\hline IV & 6 & 28.6 & & \\
\hline $\mathrm{V}$ & 1 & 4.8 & & \\
\hline \multicolumn{5}{|l|}{ Renal activity index } \\
\hline Inactive nephritis & 12 & 57.1 & & \\
\hline Active nephritis & 9 & 42.8 & & \\
\hline
\end{tabular}

the BAFF serum levels appeared to be associated with the production of anti-dsDNA antibodies of all immunoglobulin classes (IgM, IgG, and IgA).

This finding suggests that the BAFF may directly promote the derailment of $B$ cell tolerance to dsDNA by selectively driving the production of anti-dsDNA antibodies. The same authors later determined that although the cell surface expression levels of the
BAFF receptors were not significantly different between SLE patients and healthy controls, the level of BAFF receptor occupancy was greatly increased in SLE patients regardless of disease activity. ${ }^{[34]}$ The increased occupancy of BAFF receptors on SLE blood $B$ cells may contribute to the pathogenesis of SLE since it has been previously shown that the excess BAFF can rescue self-reactive $B$ cells from peripheral 


\begin{tabular}{|lcc|}
\hline \multicolumn{3}{l}{ Table 4. Clinical characteristics of patients with Behçet's } \\
disease & $\mathrm{n}$ & $\%$ \\
\hline Variables & 21 & 100.0 \\
\hline Oral ulcers & 18 & 85.7 \\
Genital ulcers & 11 & 52.4 \\
Uveitis & 8 & 38.1 \\
Deep venous thrombosis & 6 & 28.6 \\
Arthritis & 4 & 19.0 \\
Erythema nodosum & 3 & 14.3 \\
Erythema nodosum vasculitis & 1 & 4.8 \\
Pulmonary artery aneurism & 1 & 4.8 \\
Hypertension & 1 & 4.8 \\
Hepatitis & 1 & 4.8 \\
Tuberculosis & & \\
\hline
\end{tabular}

deletion. ${ }^{[35]}$ Whether elevation of the serum BAFF plays a direct role as a disease driver or whether it is simply a marker of chronic inflammation needs to be further studied.

With regard to the RA group, our study revealed no significant elevated levels of the serum BAFF when compared with the healthy control group. ${ }^{[36,37]}$ We also found significant positive correlations between the serum BAFF level and the CRP, DAS28 score, and disease control. In contrast, Becker-Merok et al. ${ }^{[31]}$ reported that the BAFF did not correlate with disease activity and showed only a weak correlation with anti-CCP antibody levels. However, the BAFF significantly correlated with the IgM-RF levels in seropositive RA patients in another study and in patients with Sjøgren's syndrome. ${ }^{[38]}$
The results of this study revealed significantly higher levels of the serum BAFF in the Behçet's group in comparison with the control group. To our knowledge, there are no previously available recorded levels of the serum BAAF in BD patients, but Sadreddini et al. ${ }^{[16]}$ reported successful treatment of a resistant case of retinal vasculitis with rituximab, which acts against the specific B cell antigen (CD20). This indicates that $\mathrm{B}$ cells must have a much broader role in the pathogenesis of $\mathrm{BD}$. As this disease is now recognized as a multisystem vasculitis, the serum BAFF level was found to be increased in patients with Wegener's granulomatosis (a rare multisystem disease characterized by necrotizing vasculitis affecting smalland medium-sized vessels of the upper and lower respiratory tracts and kidneys) compared with the healthy control group ( 1.8 versus $0.55 \mathrm{ng} / \mathrm{ml}, \mathrm{p}<0.01$ ) in a study conducted by Bader et al. ${ }^{[39]}$ The results of our study revealed a significant positive correlation between the BAFF and disease duration within the group of patients with $\mathrm{BD}$. In the same study by Bader et al., they found that the serum levels of the BAFF did not correlate with the CRP, Birmingham Vasculitis Activity Score (BVAS), Disease Extent Index (DEI), or Vasculitis Damage Index (VDI) scores in patients with Wegener's granulomatosis.

In this study, the TC levels were significantly elevated in the RA, SLE, and BD groups when compared with the control group and in the SLE group when compared with the RA and BD groups. The TG levels were significantly higher in the patients with RA, SLE,

\begin{tabular}{|c|c|c|c|c|c|}
\hline \multirow[t]{2}{*}{ Variables } & $\begin{array}{l}\text { Rheumatoid arthritis } \\
\qquad(\mathrm{n}=21)\end{array}$ & $\begin{array}{l}\text { Systemic lupus erythematosus } \\
\qquad(\mathrm{n}=21)\end{array}$ & $\begin{array}{l}\text { Behçet's disease } \\
\quad(\mathrm{n}=21)\end{array}$ & \multicolumn{2}{|c|}{$\begin{array}{l}\text { Control } \\
(\mathrm{n}=21)\end{array}$} \\
\hline & Min.-max. & Min.-max. & Min.-max. & Mean \pm SD & Min.-max. \\
\hline BAFF (pg/ml) & $\begin{array}{c}482.93 \pm 167.78 \quad 198.80-766.58 \\
\mathrm{p}<0.080\end{array}$ & $\begin{array}{c}1771.94 \pm 813.68 \quad 234.84-6300.46 \\
\mathrm{p}<0.011 ;{ }^{*} \mathrm{p}<0.024\end{array}$ & $\begin{array}{l}501.67 \pm 149.38 \quad 315.00-927.00 \\
\mathrm{p}<0.023 ;{ }^{*} \mathrm{p}<0.999 ;{ }^{* *} \mathrm{p}<0.026\end{array}$ & $342.88 \pm 184.00$ & $60.16-958.52$ \\
\hline Serum creatinine $(\mathrm{mg} / \mathrm{dl})$ & $\begin{array}{c}0.88 \pm 0.41 \quad 0.50-2.40 \\
\mathrm{p}<0.516\end{array}$ & $\begin{array}{cc}0.82 \pm 0.43 & 0.37-2.40 \\
\mathrm{p}<0.241 ; & { }^{*} \mathrm{p}<0.599\end{array}$ & $\begin{array}{cc}0.76 \pm 0.28 & 0.30-1.30 \\
\mathrm{p}<0.091 ;{ }^{*} \mathrm{p}<0.294 ; & * * \mathrm{p}<0.599\end{array}$ & $0.95 \pm 0.22$ & $0.68-1.40$ \\
\hline Total cholesterol (mg/dl) & $\begin{array}{c}175.00 \pm 14.22 \quad 145.00-195.00 \\
\mathrm{p}<0.0001\end{array}$ & $\begin{array}{c}213.29 \pm 63.35 \quad 107.00-346.00 \\
\mathrm{p}<0.0001 ;{ }^{*} \mathrm{p}<0.002\end{array}$ & $\begin{array}{l}181.76 \pm 43.90 \quad 98.0-266.00 \\
\mathrm{p}<0.0001 ;{ }^{*} \mathrm{p}<0.578 ;{ }^{* *} \mathrm{p}<0.011\end{array}$ & $120.52 \pm 5.03$ & $115.00-130.00$ \\
\hline Triglyceride (mg/dl) & $\begin{array}{c}84.81 \pm 12.34 \quad 65.00-105.00 \\
\mathrm{p}<0.014\end{array}$ & $\begin{array}{c}177.52 \pm 71.94 \quad 84.00-372.00 \\
\mathrm{p}<0.0001 ;{ }^{*} \mathrm{p}<0.0001\end{array}$ & $\begin{array}{cc}121.62 \pm 44.26 & 60.00-217.00 \\
\mathrm{p}<0.0001 ;{ }^{*} \mathrm{p}<0.007 ; & * * \mathrm{p}<0.0001\end{array}$ & $51.54 \pm 5.35$ & $44.70-62.00$ \\
\hline HDL-C (mg/dl) & $\begin{array}{c}69.76 \pm 5.37 \quad 59.00-75.00 \\
\mathrm{p}<0.923\end{array}$ & $\begin{array}{c}58.24 \pm 18.58 \quad 32.00-81.00 \\
\mathrm{p}<0.002 ;{ }^{*} \mathrm{p}<0.001\end{array}$ & $\begin{array}{cc}64.71 \pm 8.86 & 45.00-81.00 \\
\mathrm{p}<0.175 ;{ }^{*} \mathrm{p}<0.147 ; & { }^{* *} \mathrm{p}<0.064\end{array}$ & $69.43 \pm 6.79$ & $60.00-81.00$ \\
\hline LDL-C (mg/dl) & $\begin{array}{c}85.38 \pm 7.59 \quad 76.00-102.00 \\
\mathrm{p}<0.471\end{array}$ & $\begin{array}{c}161.62 \pm 33.07 \quad 78.00-200.00 \\
\mathrm{p}<0.0001 ;{ }^{*} \mathrm{p}<0.0001\end{array}$ & $\begin{array}{c}84.95 \pm 10.72 \quad 70.00-110.00 \\
\mathrm{p}<0.519 ;{ }^{*} \mathrm{p}<0.939 ;{ }^{* *} \mathrm{p}<0.0001\end{array}$ & $81.33 \pm 6.89$ & $70.00-95.00$ \\
\hline $\mathrm{CRP}(\mathrm{mg} / \mathrm{l})$ & $\begin{array}{c}36.86 \pm 19.53 \quad 17.00-70.00 \\
\mathrm{p}<0.0001\end{array}$ & $\begin{array}{c}16.00 \pm 2.77 \quad 12.00-20.00 \\
\mathrm{p}<0.0001,{ }^{*} \mathrm{p}<0.0001\end{array}$ & $\begin{array}{cc}4.22 \pm 2.98 & 0.80-10.00 \\
\mathrm{p}<0.389 ; & { }^{*} \mathrm{p}<0.0001 ;{ }^{* *} \mathrm{p}<0.0001\end{array}$ & $1.58 \pm 0.49$ & $0.90-2.50$ \\
\hline $\mathrm{ESR}(\mathrm{mm})$ & $\begin{array}{c}34.23 \pm 37.52 \quad 5.00-125.00 \\
\mathrm{p}<0.0001\end{array}$ & $\begin{array}{c}27.19 \pm 4.14 \quad 20.00-34.00 \\
\mathrm{p}<0.006 ;{ }^{*} \mathrm{p}<0.275\end{array}$ & $\begin{array}{cc}32.86 \pm 17.39 & 9.00-71.00 \\
\mathrm{p}<0.0001 ;{ }^{*} \mathrm{p}<0.830 ;{ }^{* *} \mathrm{p}<0.380\end{array}$ & $9.20 \pm 1.21$ & $7.00-12.00$ \\
\hline
\end{tabular}




\begin{tabular}{|c|c|c|c|c|c|c|c|c|}
\hline \multirow[t]{2}{*}{ Variables } & \multicolumn{2}{|c|}{$\begin{array}{l}\text { Rheumatoid arthritis } \\
(\mathrm{n}=21\end{array}$} & \multicolumn{2}{|c|}{$\begin{array}{l}\text { Systemic lupus erythematosus } \\
\qquad(\mathrm{n}=21\end{array}$} & \multicolumn{2}{|c|}{$\begin{array}{l}\text { Behçet's disease } \\
\quad(\mathrm{n}=21\end{array}$} & \multicolumn{2}{|c|}{$\begin{array}{c}\text { Control } \\
(\mathrm{n}=21\end{array}$} \\
\hline & $\mathrm{r}$ & $p$ & $\mathrm{r}$ & $p$ & $\mathrm{r}$ & $p$ & $\mathrm{r}$ & $p$ \\
\hline Age & 0.027 & $<0.906$ & 0.097 & $<0.338$ & -0.039 & $<0.868$ & 0.097 & $<0.676$ \\
\hline C-reactive protein & 0.928 & $<0.0001$ & 0.079 & $<0.367$ & -0.147 & $<0.525$ & 0.079 & $<0.734$ \\
\hline Erythrocyte sedimentation rate & 0.123 & $<0.596$ & 0.008 & $<0.486$ & 0.17 & $<0.454$ & 0.008 & $<0.973$ \\
\hline Creatinine & -0.107 & $<0.644$ & -0.248 & $<0.139$ & -0.008 & $<0.947$ & -0.248 & $<0.279$ \\
\hline Cholesterol & -0.185 & $<0.423$ & 0.217 & $<0.173$ & -0.352 & $<0.117$ & 0.217 & $<0.345$ \\
\hline Triglyceride & 0.018 & $<0.937$ & 0.205 & $<0.187$ & -0.120 & $<0.606$ & 0.205 & $<0.374$ \\
\hline High-density lipoprotein cholesterol & -0.500 & $<0.021$ & -0.126 & $<0.294$ & 0.176 & $<0.446$ & -0.126 & $<0.587$ \\
\hline Low-density lipoprotein cholesterol & -0.080 & $<0.730$ & 0.105 & $<0.326$ & 0.202 & $<0.380$ & 0.105 & $<0.652$ \\
\hline Disease duration & -0.100 & $<0.665$ & -0.016 & $<0.473$ & 0.578 & $<0.006$ & - & - \\
\hline Morning stiffness & 0.181 & $<0.431$ & - & - & - & - & - & - \\
\hline Number of swollen joints & 0.364 & $<0.105$ & - & - & - & - & - & - \\
\hline Number of tender joints & -0.140 & $<0.545$ & - & - & - & - & - & - \\
\hline DAS28 score & 0.810 & $<0.0001$ & - & - & - & - & - & - \\
\hline Disease control & 0.834 & $<0.0001$ & - & - & - & - & - & - \\
\hline Health Assessment Questionnaire total & 0.139 & $<0.548$ & - & - & - & - & - & - \\
\hline SLEDAI score classification & - & - & 0.894 & $<0.0001$ & - & - & - & - \\
\hline SLEDAI score & - & - & 0.748 & $<0.0001$ & - & - & - & - \\
\hline
\end{tabular}

and $\mathrm{BD}$ versus the healthy controls and in the patients with SLE versus those with RA and BD. They were also higher for patients with $\mathrm{BD}$ versus those with RA. The HDLC levels were significantly lower in the SLE group versus the control and RA groups. However, the LDLC levels were significantly elevated in the SLE group when compared with the control, RA and BD groups. The presentations of changes in lipid metabolism in patients with $\mathrm{BD}$ have already been reported. A study by Mitamura et al. ${ }^{[40]}$ showed that HDLC levels in male patients with BD were lower than in healthy controls, whereas very-low-density lipoprotein (VLDL) and LDLC levels tended to be higher. ${ }^{[40]}$ In addition, the same study showed no change in TC concentrations in the same patients. Lessof et al. ${ }^{[4]}$ also reported that patients with BD had low levels of HDLC.

In conclusion, the serum BAFF levels are increased in patients with SLE and BD with more elevated levels found in those with SLE. In addition, an analysis of our results leads to the conclusion that the serum BAFF levels may be associated with increased SLEDAI score, increased RA disease activity (DAS28 score), and BD duration. Thus, further studies with larger group sizes are warranted to pursue this possible correlation. These results may raise the possibility that the investigational human monoclonal antibody drug (Belimumab) can be used to reduce SLE disease activity. This drug, as has been suggested by two pivotal Phase 3 trials, BLISS-52 and BLISS-76, specifically recognizes and inhibits the biological activity of the B lymphocyte stimulator (BLyS). In lupus, it may be useful in the treatment of active resistant cases of RA and BD. When all of the research to date is taken into account, it suggests that $\mathrm{B}$ cell hyperactivity due to multiple signaling abnormalities most likely plays a central role in the development of SLE disease. Targeted therapies against the BAFF, such as BR3-Ig or TACI-Ig which target BR3 or TACI respectively or a monoclonal antibody against the BAFF, will be available for clinical practice in the near future. Understanding the expression patterns of the BAFF and its receptors will help physicians to choose appropriate targeting reagents for their patients.

\section{Declaration of conflicting interests}

The authors declared no conflicts of interest with respect to the authorship and/or publication of this article.

\section{Funding}

The authors received no financial support for the research and/or authorship of this article.

\section{REFERENCES}

1. Illei GG, Tackey E, Lapteva L, Lipsky PE. Biomarkers in systemic lupus erythematosus. I. General overview of biomarkers and their applicability. Arthritis Rheum 2004;50:1709-20. 
2. Do RK, Hatada E, Lee H, Tourigny MR, Hilbert D, ChenKiang S. Attenuation of apoptosis underlies B lymphocyte stimulator enhancement of humoral immune response. J Exp Med 2000;192:953-64.

3. Stohl W. SLE-systemic lupus erythematosus: a BLySful, yet BAFFling, disorder. Arthritis Res Ther 2003;5:136-8.

4. Gross JA, Johnston J, Mudri S, Enselman R, Dillon SR, Madden $\mathrm{K}$, et al. TACI and BCMA are receptors for a TNF homologue implicated in B-cell autoimmune disease. Nature 2000;404:995-9.

5. Lavie F, Miceli-Richard C, Quillard J, Roux S, Leclerc $\mathrm{P}$, Mariette X. Expression of BAFF (BLyS) in T cells infiltrating labial salivary glands from patients with Sjögren's syndrome. J Pathol 2004;202:496-502.

6. Thompson JS, Bixler SA, Qian F, Vora K, Scott ML, Cachero TG, et al. BAFF-R, a newly identified TNF receptor that specifically interacts with BAFF. Science 2001;293:2108-11.

7. Ng LG, Sutherland AP, Newton R, Qian F, Cachero TG, Scott ML, et al. B cell-activating factor belonging to the TNF family (BAFF)-R is the principal BAFF receptor facilitating BAFF costimulation of circulating $T$ and $B$ cells. J Immunol 2004;173:807-17.

8. Craxton A, Magaletti D, Ryan EJ, Clark EA. Macrophageand dendritic cell-dependent regulation of human B-cell proliferation requires the TNF family ligand BAFF. Blood 2003;101:4464-71.

9. Krivosikova M, Dallos T, Maslinski W, Buc M. B cell activating factor, its role in autoimmunity, and targeting in autoimmune diseases. Bratisl Lek Listy 2009;110:137-45.

10. Huard B, Schneider P, Mauri D, Tschopp J, French LE. T cell costimulation by the TNF ligand BAFF. J Immunol 2001;167:6225-31.

11. Pugh-Bernard AE, Cambier JC. B cell receptor signaling in human systemic lupus erythematosus. Curr Opin Rheumatol 2006;18:451-5.

12. Engel P, Gómez-Puerta JA, Ramos-Casals M, Lozano F, Bosch X. Therapeutic targeting of B cells for rheumatic autoimmune diseases. Pharmacol Rev 2011;63:127-56.

13. Sağdiç K, Ozer ZG, Saba D, Türe M, Cengiz M. Venous lesions in Behçet's disease. Eur J Vasc Endovasc Surg 1996;11:437-40.

14. Ames PR. Antiphospholipid antibodies, thrombosis and atherosclerosis in systemic lupus erythematosus: a unifying 'membrane stress syndrome' hypothesis. Lupus 1994;3:371-7.

15. Suh CH, Park YB, Song J, Lee CH, Lee SK. Oligoclonal B lymphocyte expansion in the synovium of a patient with Behçet's disease. Arthritis Rheum 2001;44:1707-12.

16. Sadreddini S, Noshad H, Molaeefard M, Noshad R. Treatment of retinal vasculitis in Behçet's disease with rituximab. Mod Rheumatol 2008;18:306-8.

17. Tan EM, Cohen AS, Fries JF, Masi AT, McShane DJ, Rothfield NF, et al. The 1982 revised criteria for the classification of systemic lupus erythematosus. Arthritis Rheum 1982;25:1271-7.
18. Bombardier C, Gladman DD, Urowitz MB, Caron D, Chang CH. Derivation of the SLEDAI. A disease activity index for lupus patients. The Committee on Prognosis Studies in SLE. Arthritis Rheum 1992;35:630-40.

19. Arnett FC, Edworthy SM, Bloch DA, McShane DJ, Fries JF, Cooper NS, et al. The American Rheumatism Association 1987 revised criteria for the classification of rheumatoid arthritis. Arthritis Rheum 1988;31:315-24.

20. Prevoo ML, van't Hof MA, Kuper $H H$, van Leeuwen MA, van de Putte LB, van Riel PL. Modified disease activity scores that include twenty-eight-joint counts. Development and validation in a prospective longitudinal study of patients with rheumatoid arthritis. Arthritis Rheum 1995;38:44-8.

21. Leeb BF, Haindl PM, Maktari A, Nothnagl T, Rintelen B. Disease activity score-28 values differ considerably depending on patient's pain perception and sex. J Rheumatol 2007;34:2382-7.

22. Krishnan E, Tugwell P, Fries JF. Percentile benchmarks in patients with rheumatoid arthritis: Health Assessment Questionnaire as a quality indicator (QI). Arthritis Res Ther 2004;6:R505-13.

23. Criteria for diagnosis of Behçet's disease. International Study Group for Behçet's Disease. Lancet 1990;335:1078-80.

24. Yazici H, Esen F. Mortality in Behçet's syndrome. Clin Exp Rheumatol 2008;26:S138-40.

25. Bedell SE, Bush BT. Erythrocyte sedimentation rate. From folklore to facts. Am J Med 1985;78:1001-9.

26. Katz SM. Renal disease: Classification and atlas of glomerular diseases. JAMA: The Journal of the American Medical Association 1982;248:2053-4.

27. Austin HA 3rd, Muenz LR, Joyce KM, Antonovych TA, Kullick ME, Klippel JH, et al. Prognostic factors in lupus nephritis. Contribution of renal histologic data. Am J Med 1983;75:382-91.

28. Khan WN. B cell receptor and BAFF receptor signaling regulation of $\mathrm{B}$ cell homeostasis. J Immunol 2009;183:3561-7.

29. Sunagawa S, Kouki T, Taira S, Ueda R, Yabiku K, Ikema T, et al. Serum levels of B-cell activating factor of TNF family (BAFF) as a useful indicator for the activity of Graves' disease. Journal of Endocrinology and Metabolism 2011;1:73-8.

30. Zhang J, Roschke V, Baker KP, Wang Z, Alarcón GS, Fessler BJ, et al. Cutting edge: a role for B lymphocyte stimulator in systemic lupus erythematosus. J Immunol 2001;166:6-10.

31. Becker-Merok A, Nikolaisen C, Nossent HC. B-lymphocyte activating factor in systemic lupus erythematosus and rheumatoid arthritis in relation to autoantibody levels, disease measures and time. Lupus 2006;15:570-6.

32. Zhao LD, Li Y, Smith MF Jr, Wang JS, Zhang W, Tang FL, et al. Expressions of BAFF/BAFF receptors and their correlation with disease activity in Chinese SLE patients. Lupus 2010;19:1534-49.

33. Petri M, Stohl W, Chatham W, McCune WJ, Butler T, Ryel J, et al. BLyS plasma concentrations correlate with disease activity and levels of anti-dsDNA autoantibodies and immunoglobulins (IG) in a SLE patient observational study. Arthritis and Rheumatism 2003;48:S655-S. 
34. Carter RH, Zhao H, Liu X, Pelletier M, Chatham W, Kimberly R, et al. Expression and occupancy of BAFF-R on $\mathrm{B}$ cells in systemic lupus erythematosus. Arthritis Rheum 2005;52:3943-54.

35. Thien M, Phan TG, Gardam S, Amesbury M, Basten A, Mackay F, et al. Excess BAFF rescues self-reactive B cells from peripheral deletion and allows them to enter forbidden follicular and marginal zone niches. Immunity 2004;20:785-98.

36. Cheema GS, Roschke V, Hilbert DM, Stohl W. Elevated serum B lymphocyte stimulator levels in patients with systemic immune-based rheumatic diseases. Arthritis Rheum 2001;44:1313-9.

37. Pers JO, Daridon C, Devauchelle V, Jousse S, Saraux A, Jamin C, et al. BAFF overexpression is associated with autoantibody production in autoimmune diseases. Ann N Y Acad Sci 2005;1050:34-9.
38. Mariette X, Roux S, Zhang J, Bengoufa D, Lavie F, Zhou $\mathrm{T}$, et al. The level of BLyS (BAFF) correlates with the titre of autoantibodies in human Sjögren's syndrome. Ann Rheum Dis 2003;62:168-71.

39. Bader L, Koldingsnes W, Nossent J. B-lymphocyte activating factor levels are increased in patients with Wegener's granulomatosis and inversely correlated with ANCA titer. Clin Rheumatol 2010;29:1031-5.

40. Mitamura T, Ohno S, Ariga H, Ohsaka T, Iwasaki N, Matsuda $\mathrm{H}$, et al. Lipoprotein cholesterol concentrations in patients with Behçet's disease. Clin Chim Acta 1988; 175:277-83.

41. Lessof MH, Jeffreys DB, Lehner T, Mattock M, Sanders MD. Corticosteroids and azathioprine: their use in Behćet's syndrome. In: Lehner T, Barnes CG, editors. Behćet's syndrome: clinical and immunological features. London: Academic Press; 1979. p. 218-26. 